\title{
Inovasi Pengembangan Sistem Informasi Pengelolaan Surat Keterangan Pendamping Ijazah Berbasis Web
}

\author{
Tito Sugiharto, Mohammad Irwansyah* \\ Fakultas Ilmu Komputer, Program Studi Teknik Informatika, Universitas Kuningan, Kuningan, Indonesia \\ Email: ${ }^{1}$ tito@uniku.ac.id, ${ }^{2,}{ }^{*}$ mirwansyah1933@gmail.com \\ Email Penulis Korespondensi: mirwansyah1933@gmail.com
}

\begin{abstract}
Abstrak-Penelitian ini dibuat bertujuan untuk menghasilkan suatu sistem informasi pengelolaan Surat Keterangan Pendamping Ijazah (SKPI). Target penelitian yang ingin dicapai adalah adanya sebuah sistem informasi yang dapat digunakan untuk mengelola pengisian dan pencetakan Surat Keterangan Pendamping Ijazah. Sistem informasi pengelolaan Surat Keterangan Pendamping Ijazah ini dibuat untuk diterapkan di Program Studi Teknik Informatika S1 Fakultas Ilmu Komputer Universitas Kuningan. Penelitian ini membahas bagaimana proses merancang dan mengembangkan sebuah sistem informasi untuk pengelolaan Surat Keterangan Pendamping Ijazah di Program Studi Teknik Informatika S1. Belum adanya sebuah aplikasi atau sistem informasi untuk pengelolaan Surat Keterangan Pendamping Ijazah menjadi masalah serius yang harus diperhatikan. Pengelola Program Studi Teknik Informatika S1 merasa kesulitan dalam proses pembuatan dan pengisian Surat Keterangan Pendamping Ijazah untuk lulusannya. Dengan tidak adanya sistem informasi pengelolaan Surat Keterangan Pendamping Ijazah proses pembuatan dan pengisian Surat Keterangan Pendamping Ijazah akan memakan waktu yang lama. Metodologi yang digunakan dalam penelitian ini adalah Rational Unified Process (RUP). Terdapat empat tahapan dalam penggunaan metodologi RUP ini, yaitu tahapan inception, elaboration, contruction, dan transition. Model perancangan yang digunakan dalam penelitian ini menggunakan Unified Modelling Language(UML). Proses pengujian dilakukan dengan menggunakan Black Box Testing. Oleh karena itu, untuk menyelesaikan permasalahan tersebut maka diperlukan sebuah inovasi dalam pengelolaan Surat Keterangan Pendamping Ijazah berbasis web. Diharapkan dengan adanya sistem informasi tersebut dapat membantu dan mempermudah Program Studi dalam pengelolaan Surat Keterangan Pendamping Ijazah.
\end{abstract}

Kata Kunci: Inovasi, SKPI, Web, RUP, UML

Abstract-This research was aiming to produce a management information system for Diploma Companion Certificate (SKPI). The target of the research to be achieved is the existence of an information system that can be used to manage the filling and printing of Companion Certificates. Management information system This Certificate of Companion is made to be applied in the Informatics Engineering Study Program S1 Faculty of Computer Science, University of Kuningan. This study discusses how the process of designing and developing an information system for managing Diploma Certificates of Completion in the S1 Informatics Engineering Study Program. The absence of an application or information system for managing Diploma Certificates is a serious problem that must be considered. Managers of the S1 Informatics Engineering Study Program find it difficult in the process of making and filling Diploma Companion Certificates for their graduates. In the absence of a management information system, a Diploma of Companion Certificate, the process of making and filling with Certificate ofCompanion Certificate will take a long time. The method used in this study is Rational Unified Process (RUP). There are four stages in the use of this RUP method, namely the stages of inception, elaboration, construction and transition. The design model used in this study uses Unified Modeling Language (UML). The testing process is carried out using the Black Box Testing. Therefore, to solve these problems, an innovation is needed In the management ofa web-based Diploma Companion Certificate. It is expected that this information system can help and ease the Study Program in managing Diploma Companion Certificates.

Keywords: Innovation, SKPI, Web, RUP, UML

\section{PENDAHULUAN}

Surat Keterangan Pendamping Ijazah yang selanjutnya disingkat SKPI adalah sebuah dokumen resmi yang memuat informasi tentang pemenuhan kompetensi lulusan dalam suatu Program Pendidikan Tinggi[1]. Surat Keterangan Pendamping Ijazah ini berisi pencapaian akademik, capaian pembelajaran, dan kualifikasi lulusan perguruan tinggi. Surat Keterangan Pendamping Ijazah dapat digambarkan sebagai sebuah rekam jejak mahasiswa ketika menjalani perkuliahan dan menjadi sebuah dokumen pendukung semua prestasi dan sertifikasi yang dicantumkan di daftar riwayat hidup. SKPI berisi uraian secara naratif capaian pembelajaran lulusan selama mengikuti perkuliahan di Perguruan Tinggi[2].

Surat Keterangan Pendamping Ijazah dibuat dan dikeluarkan dengan tujuan untuk mendampingi ijazah dan transkip akademik. Ijazah menjadi sebuah bukti telah selesainya suatu jenjang pendidikan tertentu dan transkip nilai menerangkan daftar nilai pencapaian selama menempuh perkuliahan. Sedangkan Surat Keterangan Pendamping Ijazah menerangkan kemampuan yang dibutuhkan sebagai prasayarat dalam persaingan dunia kerja dilihat dari latar belakang kompetensinya.

Menurut Undang-Undang Nomor 12 tahun 2012 tentang Pendidikan Tinggi dan Pengelolaan Perguruan Tinggi dalam Pasal 44 ayat 1 sampai ayat 3[3] mengharuskan setiap perguruan tinggi memberikan sertifikat kompetensi bagi setiap lulusannya sebagai keterangan resmi tentang kompetensi setiap mahasiswa sekaligus dapat digunakan untuk mendapatkan pekerjaan. Dalam bidang pendidikan seperti yang ada dalam Perguruan Tinggi baik negeri maupun swasta sangat membutuhkan dukungan dalam proses komunikasi data [4]. 
Fakultas ilmu komputer adalah salah satu fakultas yang ada di Universitas Kuningan[5].Program Studi Teknik Informatika S1 Fakultas Ilmu Komputer Universitas Kuningan mulai mempersiapkan lulusannya untuk memiliki Surat Keterangan Pendamping Ijazah. Namun dalan proses pembuatan dan pengerjaannya belum adanya sistem informasi untuk pengelolaan Surat Keterangan Pendamping Ijazah, hal ini menyebabkan proses pembuatan Surat Keterangan Pendamping Ijazah menjadi lebih lama dan lebih rumit. Belum adanya sistem informasi pengelolaan Surat Keterangan Pendamping Ijazah juga menyebabkan monitoring dan evaluasi sulit untuk dilakukan oleh pimpinan universitas.

Oleh karena itu, untuk menyelesaikan permasalahan tersebut maka diperlukan sebuah inovasi dalam pembuatan dan pengelolaan Surat Keterangan Pendamping Ijazah di Program Studi Teknik Informatika S1. Diharapkan dengan adanya sistem informasi pengelolaan Surat Keterangan Pendamping Ijazah dapat mempermudah Program Studi dalam pembuatan dan pelaporan.

Berdasarkan latar belakang masalah diatas, maka peneliti dapat merumuskan permasalahan sebagai berikut: bagaimana merancang dan membuat Sistem Informasi Pengelolaan Surat Keterangan Pendamping Ijazah Berbasis Web?, bagaimana langkah-langkah dalam proses pembuatan Sistem Informasi Pengelolaan Surat Keterangan Pendamping Ijazah? dan bagaimana menggunakan Sistem Informasi Pengelolaan Surat Keterangan Pendamping Ijazah dengan baik dan mudah?

\section{METODE PENELITIAN}

Metode penelitian yang digunakan terdapat dua yaitu: metode pengumpulan data dan metode pengembangan sistem. Pada metode pengumpulan data dilakukan tiga metode pengumpulan data, yaitu: metode wawancara, metode observasi, dan metode studi pustaka. Metode wawancara digunakan ketika mencari data awal tentang tempat penelitian, objek penelitian, proses pembuatan SKPI dan menentukan kebutuhan fungsional serta kebutuhan non fungsional. Metode observasi merupakan suatu metode yang dilakukan dengan cara melakukan pengamatan secara langsung terhadap obyek yang akan diteliti. Metode studi pustaka merupakan suatu metode yang dilakukan dengan menggunakan literatur yang digunakan.

Metode pengembangan sistem yang dilakukan dalam penelitian ini adalah menggunakan metode pengembangan sistem Rational Unified Process (RUP). Menurut Amwar (2014) RUP merupakan sebuah proses berulang untuk mengembangkan sebuah perangkat lunak[6]. Model RUP sangat bagus untuk digunakan untuk proses pengembangan perangkat lunak berbasis Unified Modeling Language (UML), hal ini dikarenakan metode RUP memakai cara-cara Object Oriented Programming (OOP) dalam mebagi tahapan demi tahapan[7].

Terdapat empat tahapan dalam metode pengembangan sistem RUP, yaitu: tahap inception, tahap elaboration, tahap contruction, dan tahap transition. Tahapan dalam metode pengembangan RUP dapat dilihat pada gambar 1. Tahap inception menggambarkan proses bisnis yang sekarang berjalan dan akan dijadikan acuan untuk menganalisa kebutuhan pembuatan sistem[8].Pada tahap inception dilakukan pengelompokan kebutuhan fungsional dan kebutuhan non fungsional dari sistem yang akan dibangun. Pada tahap elaboration digunakan untuk mematangkan konsep-konsep yang sudah terbentuk di fase inception[9]. Pada tahap ini dilakukan perancangan sistem menggunakan pemodelan UML mulai dari pembuatan use case diagram, activity diagram, class diagram, dan sequence diagram. Perancangan UML adalah teknik untuk merancang sebuah sistem serta aplikasinya, UML adalah bahasa yang menentukan, memvisualisasikan, membangun dan mendokumentasikan suatu sistem informasi yang akan dirancang[10]. Pada tahap contruction dilakukan pengerjaan pembuatan kode program dari sistem yang akan dibangun. Kemudian pada tahapan transition dilakukan tahapan pengujian menggunakan pengujian Black Box testing. Metode ini dilakukan dengan cara menjalankan atau mengeksekusi program yang dihasilkan[11].

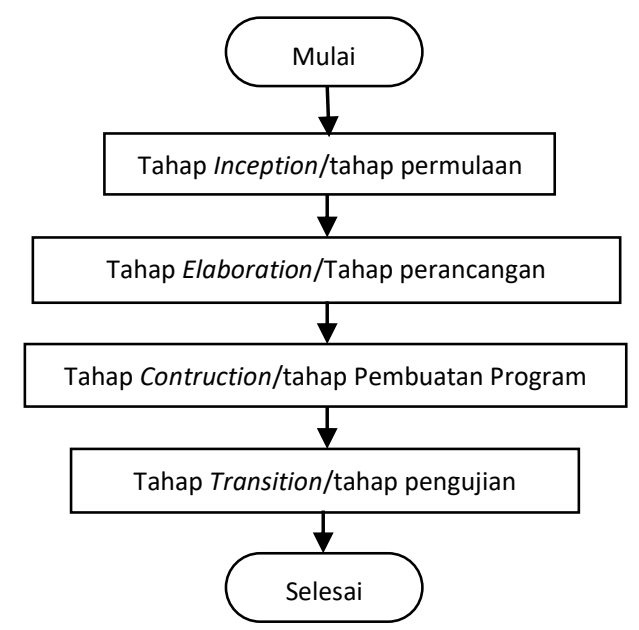

Gambar 1. Gambar tahapan metode penelitian Rational Unified Process(RUP) 


\section{HASIL DAN PEMBAHASAN}

Tahap perancangan sistem dalam penelitian ini menggunakan pemodelan UML. Alat bantu UML digunakan untuk menganalisis dan merancang sistem usulan[12]. UML merupakan bahasa standar yang digunakan untuk menjelaskan dan memvisualisasikan rancangan proses analisis dan desain berorientasi objek. Use Case Diagram mendeskripsikan sistem/aplikasi, lingkungan dan relasi antara sistem/aplikasi dengan lingkungannya. Dalam aplikasi yang dibuat, aktor memiliki beberapa perlakuan umum yang dapat dilakukan. Use Case Diagram menggambarkan pengguna dengan aplikasi. Pada gambar 2 dapat kita lihat Use Case Diagram untuk penelitian ini.

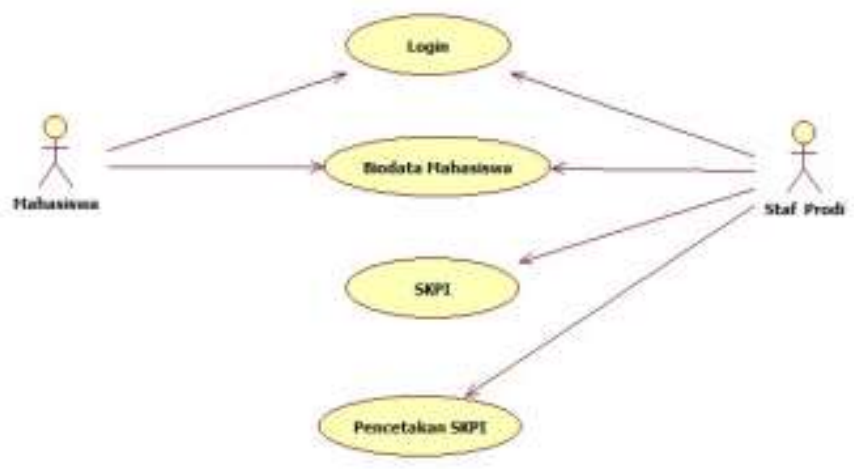

Gambar 2. Gambar use case diagram sistem informasi

Gambar 2 menunjukan bahwa terdapat satu user yang memiliki beberapa tindakan pada menu utama, yaitu Pada bagan ini akan dijelaskan masing-masing deskripsi dari Use Case Diagram yang dilakukan oleh Staf Prodi dan Mahasiswa per Use Case nya, mulai dari Staf Prodi dan Mahasiswa, pengolahan biodata mahasiswa, SKPI, dan Pencetakan.

Activity Diagram merupakan gambaran aliran kejadian suatu aplikasi. Diagram aktifitas berfungsi untuk memberikan gambaran aliran aktifitas dari aplikasi atau sistem yang sedang dibangun[13]. Pada activity diagram ini menggambarkan proses yang berjalan di sistem yang dilakukan oleh pengguna dari awal membuka aplikasi sampai menutup aplikasi. Gambar 3 merupakan activity diagram login.

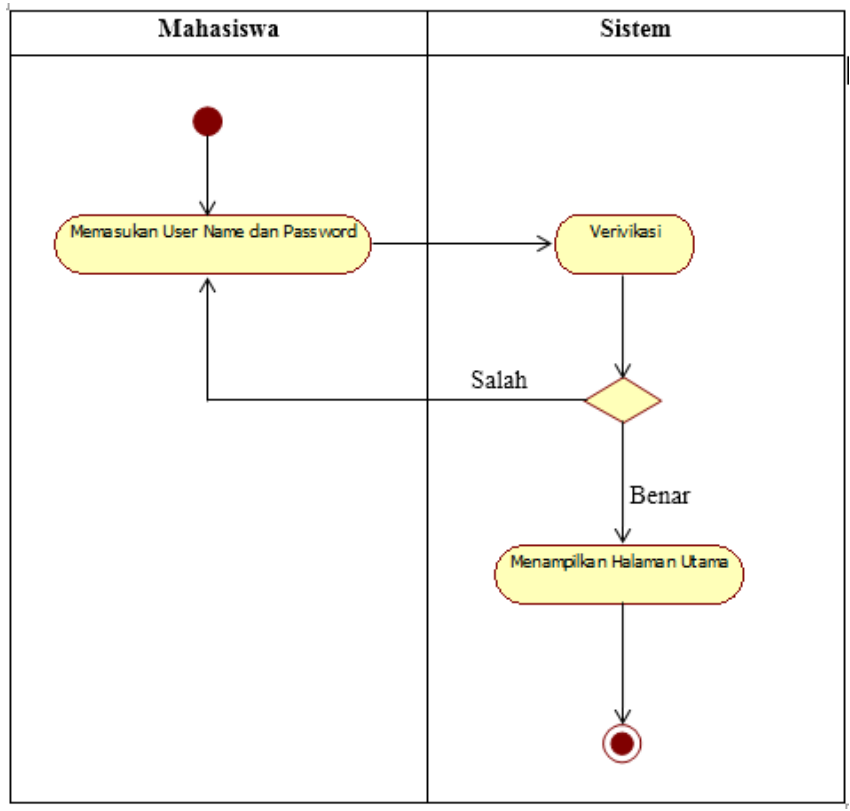

Gambar 3. Gambar activity diagram Login

Perancangan ini akan menampilkan aksi maupun reaksi yang didapat akibat interaksi yang diberikan. Proses selanjutnya, setelah dibuat activity diagram adalah membuat sequence diagram. Sequence diagram digunakan untuk menggambarkan skenario atau rangkaian langkah-langkah yang dilakukan sebagai sebuah respon dari suatu kejadian untuk menghasilkan output. Adapun sequence diagram yang dirancang dari aplikasi ini digambarkan pada Gambar 4. 


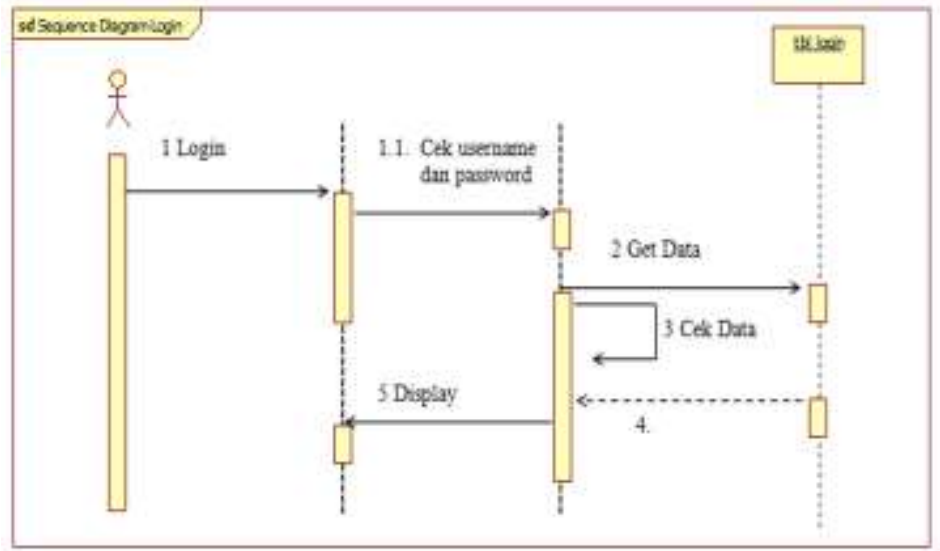

Gambar 4. Gambar sequence diagram login

Setelah tahapan Inception dan Elaboration dilakukan, maka selanjutnya akan dilakukan tahapan Construction dan Transition. Pada tahapan Construction akan lebih fokus pada hasil perancangan tampilan dan menu-menu yang diusulkan. Sementara itu, pada tahapan Transition lebih fokus pada proses pengujian dari aplikasi yang dirancang.

\subsection{Implementasi}

Setelah mengalami sederetan proses iterasi, pada tahapan Construction ini sudah dapat menghasilkan suatu aplikasi. Halaman tampilan awal merupakan halaman awal yang pertama kali muncul ketika aplikasi dijalankan. Gambar 5 merupakan hasil dari halaman awal.

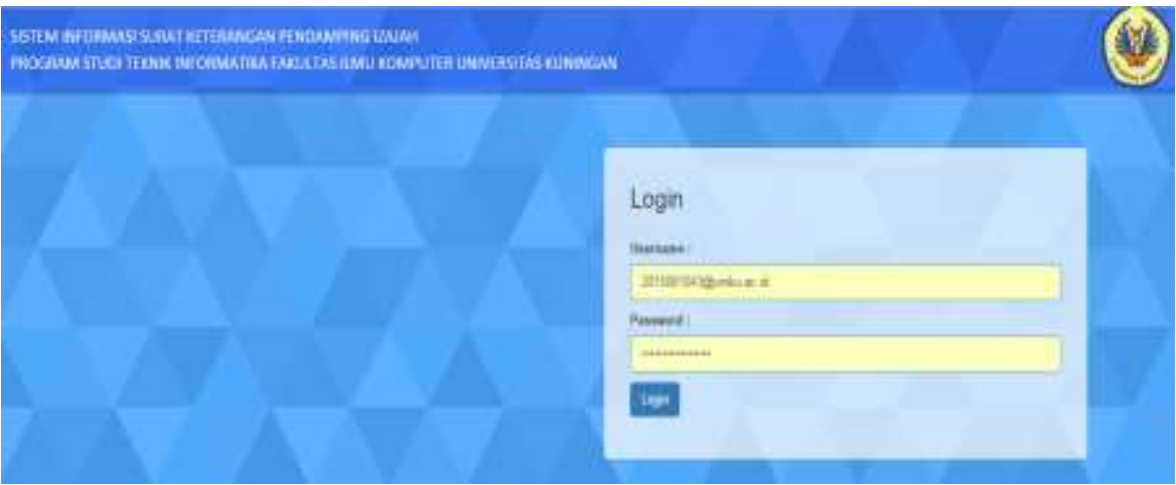

Gambar 5. Gambar Halaman Awal

Halaman staf prodi akan tampil jika pengguna memasukan nama dan paswword yang benar untuk login sebagai staf prodi. Halaman staf prodi ini digunakan oleh staf prodi untuk mengelola data SKPI. Gambar 6 . menggambarkan hasil dari pembuatan halaman staf prodi.

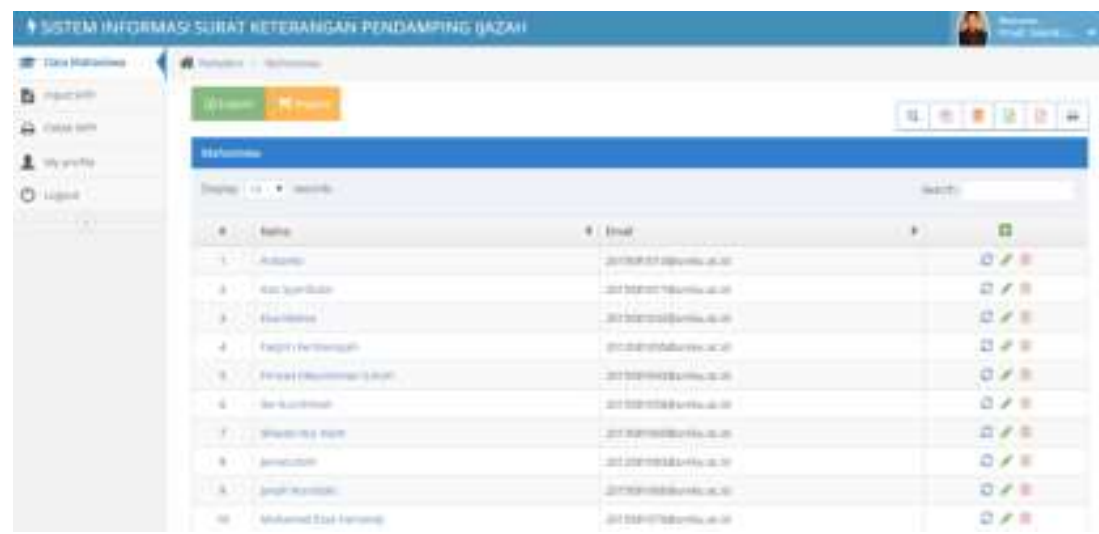

Gambar 6. Tampilan Halaman Staf Prodi

Halaman ini merupakan halaman yang digunakan oleh staf prodi untuk memasukan data isian Surat Keterangan Pendamping Ijazah (SKPI). Staf prodi dapat memilih nama mahasiswa kemudian mengecek isian 
JURNAL MEDIA INFORMATIKA BUDIDARMA

Volume 4, Nomor 2, April 2020, Page 325-331

ISSN 2614-5278 (media cetak), ISSN 2548-8368 (media online)

Available Online at https://ejurnal.stmik-budidarma.ac.id/index.php/mib

DOI 10.30865/mib.v4i2.1903

data dari mahasiswa dan memasukan data tambahan untuk isian SKPI sesuai dengan data masing-masing mahasiswa. Gambar 7 merupakan gambar tampilan halaman input SKPI.

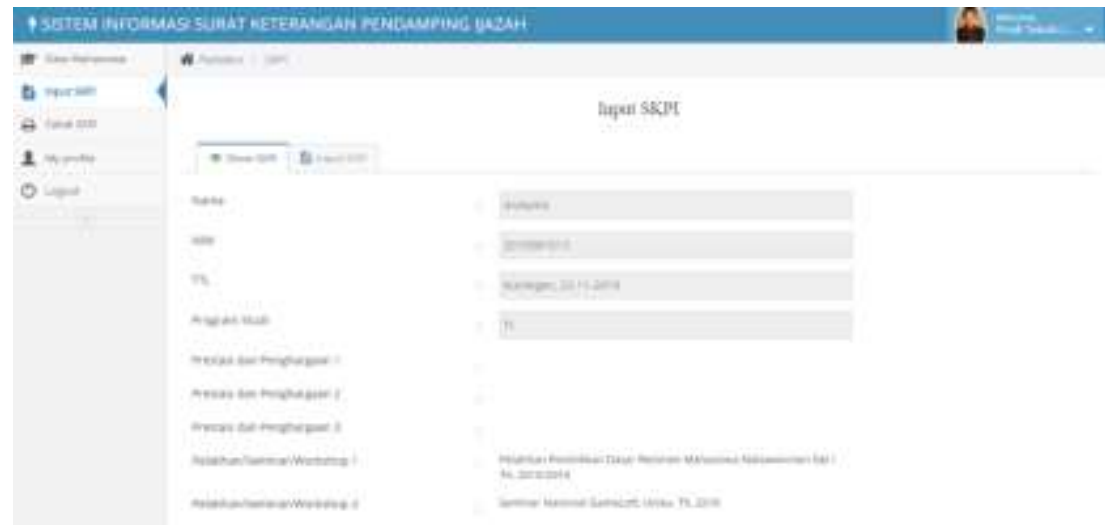

Gambar 7. Tampilan Halaman Input SKPI

Pada Gambar 7 terdiri dari beberapa isian data yang harus dimasukan oleh staf prodi untuk melengkapi isian data SKPI dari masing-masing mahasiswa. Pada halaman cetak SKPI terdapat pilihan untuk mencetak SKPI. Pada halaman ini juga terdapat data mahasiswa yang sudah mengisi biodata dan sudah diisi SKPI nya oleh staf program studi.

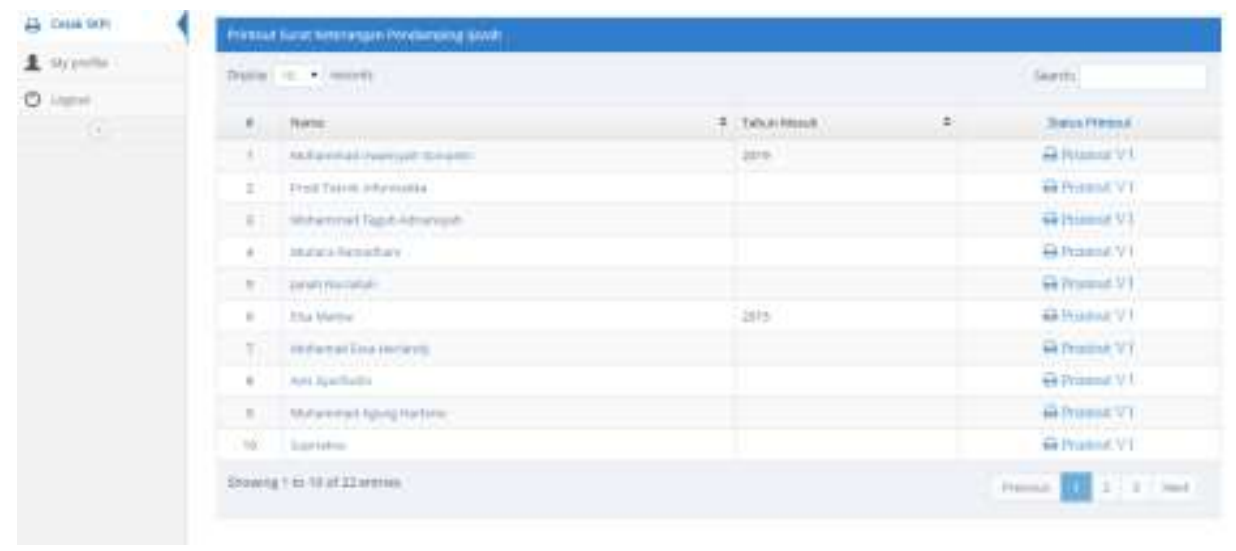

Gambar 8. Tampilan Halaman Cetak SKPI

Pada Gambar 8 merupakan tampilan halaman cetak SKPI. Pada halaman review ini muncul setelah staf prodi menekan tombol printout SKPI. Halaman ini digunakan untuk melihat isian data sebelum SKPI dicetak oleh staf prodi.Gambar 9 merupakan gambara mengenai halaman review yang digunakan untuk melihat hasil isian SKPI.

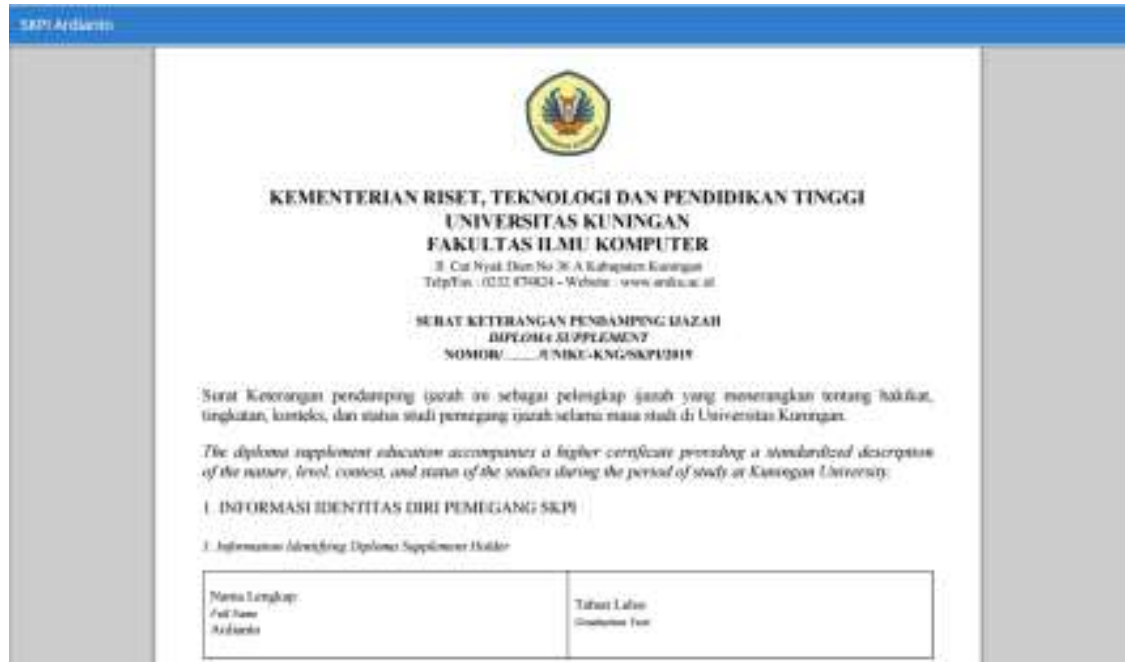

Gambar 9. Tampilan Halaman Review 
Pada halaman My Profile berisi tentang data pengguna, pada halaman ini terdapat username, nama, email, tempat lahir, tanggal lahir, dan rubah password. Gambar 10 merupakan tampilan dari halaman My Profile.

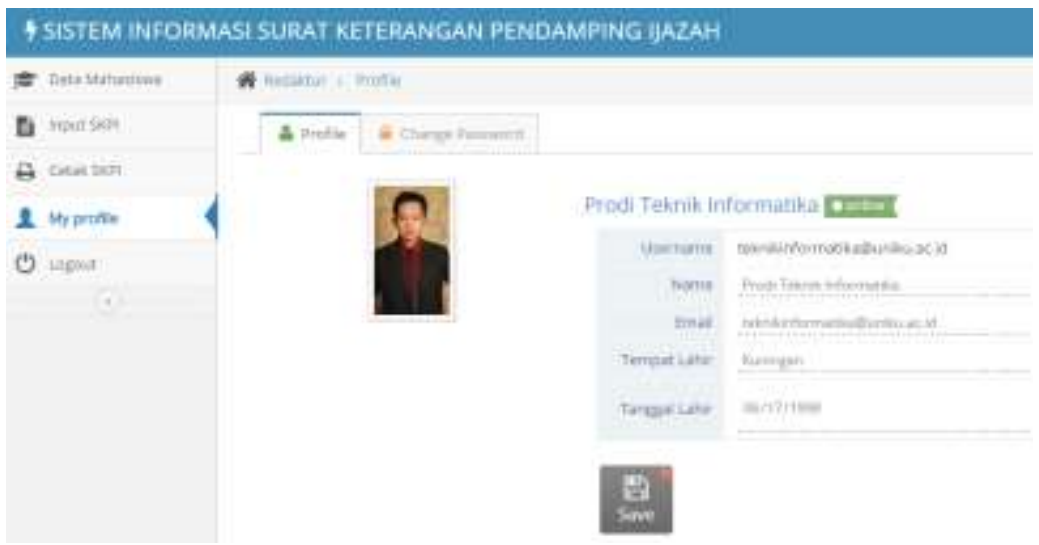

Gambar 10. Tampilan Halaman My Profile

Tahap Transition merupakan tahapan akhir dari proses RUP. Dalam tahapan ini lebih difokuskan pada masalah pengujian. Proses pengujian sendiri memiliki banyak jenis. Proses pengujian adalah proses mengeksekusi aplikasi untuk menentukan apakah apliaksi perangkat lunak tersebut cocok dengan spesifikasi sistem dan berjalan sesuai dengan lingkungan yang diinginkan.

Tahap pengujian merupakan elemen kritis dari kualitas aplikasi perangkat lunak yang telah dibangun dan mempresentasikan kajian pokok dari spesifikasi, perancangan dan proses pengkodean.

Pengujian BlackBox adalah proses pengujian aspek fundamental aplikasi tanpa memperhatikan struktur logika internal perangkat lunak. Proses pengujian ini dilakukan untuk mengetahui apakah aplikasi perangkat lunak dapat berjalan dan berfungsi dengan benar. Proses pengujian blackbox dilakukan pada Menu. Adapun hasil pengujian blackbox yang telah dilakukan pada Menu File bagian Masukan Citra dapat dilihat pada Tabel 1.

Tabel 1. Hasil Pengujian BlackBox Testing

\begin{tabular}{|c|c|c|c|c|}
\hline No & Fungsi yang diuji & Cara menguji & Hasil yang diharapkan & Hasil yang keluar \\
\hline 1 & Cek Login & $\begin{array}{l}\text { User melakukan Login ke } \\
\text { sistem }\end{array}$ & Tampil Menu Utama & $\begin{array}{c}\text { Sesuai dengan harapan } \\
\text { Valid }\end{array}$ \\
\hline 2 & $\begin{array}{l}\text { Cek Menu Input } \\
\text { Biodata }\end{array}$ & $\begin{array}{l}\text { Mahasiswa melakukan input } \\
\text { biodata }\end{array}$ & Biodata tersimpan di sistem & $\begin{array}{c}\text { Sesuai dengan harapan } \\
\text { Valid }\end{array}$ \\
\hline 3 & $\begin{array}{l}\text { Cek Menu My } \\
\text { Profile }\end{array}$ & $\begin{array}{l}\text { Mahasiswa melihat menu My } \\
\text { Profile }\end{array}$ & $\begin{array}{l}\text { Berpindah ke halaman My } \\
\text { Profile }\end{array}$ & $\begin{array}{c}\text { Sesuai dengan harapan } \\
\text { Valid }\end{array}$ \\
\hline 4 & $\begin{array}{c}\text { Cek Menu Cetak } \\
\text { SKPI }\end{array}$ & $\begin{array}{l}\text { Mahasiswa mengklik menu } \\
\text { cetak SKPI }\end{array}$ & $\begin{array}{l}\text { Muncul tampilan review } \\
\text { untuk mencetak halaman } \\
\text { SKPI }\end{array}$ & $\begin{array}{c}\text { Sesuai dengan harapan } \\
\text { Valid }\end{array}$ \\
\hline 5 & Cek Menu Logout & $\begin{array}{l}\text { Mahasiswa mengklik menu } \\
\text { Logout }\end{array}$ & Keluar dari sistem & $\begin{array}{c}\text { Sesuai dengan harapan } \\
\text { Valid }\end{array}$ \\
\hline 6 & $\begin{array}{l}\text { Cek Menu Input } \\
\text { SKPI }\end{array}$ & $\begin{array}{l}\text { Staf Prodi menginput isian } \\
\text { SKI }\end{array}$ & $\begin{array}{c}\text { Dapat menyimpan isian } \\
\text { data SKPI }\end{array}$ & $\begin{array}{c}\text { Sesuai dengan harapan } \\
\text { Valid }\end{array}$ \\
\hline
\end{tabular}

\section{KESIMPULAN}

Berdasarkan hasil implementasi dan pembahasan yang telah dilakukan, maka dapat ditarik kesimpulan sebagai berikut.

1. Dapat dihasilkannya sebuah sistem informasi untuk pengelolaan Surat Keterangan Penamping Ijazah menggunakan bahasa pemrograman PHP dan databse MySQL yang mudah digunakan dan menarik.

2. Dengan adanya sistem informasi ini staf program studi dapat dengan mudah untuk membuat dan mengelola Surat Keterangan Pendamping Ijazah yang akan dicetak.

3. Sistem informasi dapat berjalan di komputer/nootbook yang telah terinstal browser.

\section{REFERENCES}

[1] D. P. T. MENTERI RISET, TEKNOLOGI and R. INDONESIA, "Permenristekditki No59 Tahun $2018, " 2018$.

[2] Sarwanto, "Prosiding Seminar Nasional Fisika dan Pendidikan Fisika (SNFPF)," vol. 6, no. pasal 6, p. 5, 2014.

[3] P. Indonesia, "Undang-Undang Republik Indonesia Nomor 12 Tahun 2012 Tentang Pendidikan Tinggi,” vol. 66, pp. 37-39, 2012. 
JURNAL MEDIA INFORMATIKA BUDIDARMA

Volume 4, Nomor 2, April 2020, Page 325-331

ISSN 2614-5278 (media cetak), ISSN 2548-8368 (media online)

Available Online at https://ejurnal.stmik-budidarma.ac.id/index.php/mib

DOI 10.30865/mib.v4i2.1903

[4] I. Salamah, L. Lindawati, and H. Y. Sitompul, “Aplikasi Bimbingan Tugas Akhir Menggunakan Notifikasi Berbasis Android,” J. Media Inform. Budidarma, vol. 3, no. 3, p. 232, 2019, doi: 10.30865/mib.v3i3.1216

[5] R. A. Krisdiawan, "Rancang Bangun Sistem Informasi Judul Dan Pembimbing Skripsi /Tugas Akhir Fkom Uniku," Buffer Inform., vol. 3, no. 1, pp. 1-8, 2018, doi: 10.25134/buffer.v4i1.1135

[6] A. Anwar, "A Review of RUP ( Rational Unified Process ),” no. 5, pp. 8-24, 2014.

[7] T. Sugiharto, T. Informatika, and U. Kuningan, "Rancang Bangun Sistem Pengelolaan Bimbingan Mahasiswa Dengan Dosen Pembimbing Akademik Berbasis Web," Buffer Inform., vol. Vol.01 No., 2015.

[8] O. Novitasari, "Implementasi Rational Unified Process Pada Sistem Informasi Simpan Pinjam Kelompok Perempuan," CITISEE, no. 2016, pp. 126-129, 2017.

[9] G. P. Hartawan, "Implementasi Rational Unified Process Dalam Sistem Informasi E-Sekolah,” J. SANTIKA, vol. Vol.07 No., pp. 563570, 2017.

[10] K. T. Naramessakh and C. Prianto, "Rancang Bangun Aplikasi Penentuan Kelayakan Pemberian Pinjaman Kepada Pensiun Menggunakan Metode Weighted Product," vol. 3, no. 4, pp. 324-333, 2019, doi: 10.30865/mib.v3i4.1289.

[11] A. Yusnita, H. Ekawati, and N. R. Wati, "Penerapan Metode Pewarnaan Graf Untuk Penjadwalan Mata Kuliah," J. Media Inform. Budidarma, vol. 3, no. 3, p. 153, 2019, doi: 10.30865/mib.v3i3.1102.

[12] R. Zendrato and A. U. Hamdani, "Pemodelan Sistem Informasi Pengadaan Alat dan Bahan Praktikum Menggunakan Unified Modeling Language (Studi Kasus: Program Pendidikan Dokter Gigi Spesialis Konservasi Gigi Fakultas Kedokteran Gigi Universitas XYZ)," Konf. Nas. Teknol. Inf. dan Komput., vol. I, no. 1, pp. 86-95, 2017.

[13] H. Budianto and E. Kurniadi, "RANCANG BANGUN APLIKASI INFORMASI SARANA KESEHATAN Di KABUPATEN KUNINGAN MENGGUNAKAN METODE LOCATION BASED SERVICE ( LBS ) BERBASIS ANDROID,” vol. 4, pp. 8-15, 2019 